\title{
The psychological impact of the COVID-19 pandemic on adults and children in the United Arab Emirates: a nationwide cross- sectional study
}

\author{
Basema Saddik ${ }^{1,2}$, Amal Hussein ${ }^{1}$, Ammar Albanna ${ }^{3,4}$, Iffat Elbarazi ${ }^{5}$, Arwa Al-Shujairi ${ }^{2}$, Mohamad-Hani Temsah ${ }^{6,7}$,
} Fatemeh Saheb Sharif-Askari ${ }^{2}$, Emmanuel Stip ${ }^{8}$, Qutayba Hamid ${ }^{2,9}$ and Rabih Halwani ${ }^{2, *^{*}}$

\begin{abstract}
Background: The psychosocial impact of previous infectious disease outbreaks in adults has been well documented, however, there is limited information on the mental health impact of the COVID-19 pandemic on adults and children in the United Arab Emirate (UAE) community. The aim of this study was to explore anxiety levels among adults and children in the UAE and to identify potential risk and protective factors for well-being during the COVID-19 pandemic.
\end{abstract}

Methods: Using a web-based cross-sectional survey we collected data from 2200 self-selected, assessed volunteers and their children. Demographic information, knowledge and beliefs about COVID-19, generalized anxiety disorder (GAD) using the (GAD-7) scale, emotional problems in children using the strengths and difficulties questionnaire (SDQ), worry and fear about COVID-19, coping mechanisms and general health information were collected. Descriptive analysis was carried out to summarize demographic and participant characteristics, Chi-square analysis to explore associations between categorical variables and anxiety levels and multivariable binary logistic regression analysis to determine predictors of anxiety levels in adults and emotional problems in children.

Results: The overall prevalence of GAD in the general population was $71 \%$ with younger people (59.8\%) and females (51.7\%) reporting highest levels of anxiety. Parents who were teachers reported the highest percentage of emotional problems in children (26.7\%). Adjusted multivariable logistic regression for GAD-7 scores showed that being female, high levels of worry associated with COVID-19, intention to take the COVID-19 vaccine and smoking were associated with higher levels of anxiety. Adjusted multivariable logistic regression for SDQ showed that higher emotional problems were reported for children in lower and higher secondary education, and parents who had severe anxiety were seven times more likely to report emotional problems in their children.

(Continued on next page)

\footnotetext{
* Correspondence: rhalwani@sharjah.ac.ae

${ }^{2}$ Sharjah Institute of Medical Research, University of Sharjah, Sharjah, United Arab Emirates

${ }^{9}$ Department of Clinical Sciences, College of Medicine, University of Sharjah, Sharjah, United Arab Emirates

Full list of author information is available at the end of the article
}

(c) The Author(s). 2021 Open Access This article is licensed under a Creative Commons Attribution 4.0 International License, which permits use, sharing, adaptation, distribution and reproduction in any medium or format, as long as you give appropriate credit to the original author(s) and the source, provide a link to the Creative Commons licence, and indicate if changes were made. The images or other third party material in this article are included in the article's Creative Commons licence, unless indicated otherwise in a credit line to the material. If material is not included in the article's Creative Commons licence and your intended use is not permitted by statutory regulation or exceeds the permitted use, you will need to obtain permission directly from the copyright holder. To view a copy of this licence, visit http://creativecommons.org/licenses/by/4.0/ The Creative Commons Public Domain Dedication waiver (http://creativecommons.org/publicdomain/zero/1.0/) applies to the data made available in this article, unless otherwise stated in a credit line to the data. 
(Continued from previous page)

Conclusions: This study reports the psychological impact of COVID-19 among adults and children in the UAE and highlights the significant association between parental and child anxiety. Findings suggest the urgency for policy makers to develop effective screening and coping strategies for parents and especially children.

Keywords: COVID-19, Anxiety, Children, Adult, United Arab Emirates

\section{Background}

The coronavirus disease 2019 (COVID-19) emerged in Wuhan, China, December 2019, and was declared a public health emergency on January 30th 2020 [1] and a global pandemic by the World Health Organization (WHO) on March 11th [2]. By March 7th, 2021, 1 year after it was declared a pandemic, more than 117 million confirmed cases and almost 3 million deaths were reported worldwide, with 408,236 confirmed cases and 1310 deaths in the UAE [3]. In the absence of effective treatments and vaccines during the early stages of the pandemic, unprecedented public health interventions were implemented across the UAE to curb transmission of the disease. These included international border closures, travel bans, lockdowns, closures of schools and universities, strict social distancing, lockdowns and quarantines. These measures, along with fear of the pandemic and disruption in people's lives have significant mental health implications [4].

Research on past infectious disease outbreaks, such as severe acute respiratory syndrome (SARS), swine flu, and influenza revealed a wide range of psychosocial impacts at individual, community, and international levels. These included worries about becoming infected and fear of dying [5], increase in anxiety, post-traumatic stress and depression [6], feelings of helplessness, guilt, panic and increased perception of risk [7-9]. More recently, studies investigating the psychological impacts of COVID-19 in China, Spain, Italy, India and the UK have reported moderate to severe stress, generalized anxiety, insomnia, and depression [10-16] associated with lockdowns, social isolation, changes in daily habits, public fear and worry.

Information about the mental health impact of COVID-19 on the UAE population is scarce. An earlier study explored the psychosocial correlates (COVID-19 infection status, mental health history, living arrangements and demographic variables) with depression and anxiety and reported high levels of anxiety and depression among segments of the UAE population [17]. However, no study has yet investigated correlates of anxiety with precautionary measures undertaken and lockdowns, coping mechanisms and perceptions of fear and worry. Furthermore, there are no published reports on the mental health impact of this pandemic on children. While severe COVID-19 is less frequent in children than in adults [18], the mental health of children may be disproportionately affected due to changes in their routines, school disruptions, reduction in social contact and fear of the unknown, all of which can cause heightened anxiety and impact on their well-being [19, 20].Previous pre-pandemic research from the UAE reports high levels of anxiety among adolescents [21] making this an especially vulnerable group to develop mental health problems because of the unique combination of the public health crisis, limited social contact, and schooling disruption [20]. Additionally, the impact of traumas and disasters on children's mental health has been found to be influenced by the impact of post disaster traumas on parents, parenting, parent-child interactions, and the family environment [22]. With recent evidence on how parental anxiety can contribute to anxiety disorders in children [23-25] and the relationship between parental anxiety and child symptomatology [26, 27], the mental well-being of children during this pandemic should not be ignored. Parent and teacher observations are important in screening for psychological and emotional disorders in children and play a significant role in being key informants and data sources for measuring child psychosocial well-being $[28,29]$. Furthermore, in times of paramount stress and uncertainty, parents and secure family environments are considered a safe haven for children and serve as strong protective factors against stress and anxiety. As observers and key informants, parents and teachers can positively influence children's well-being $[30,31]$.

In this study, we explored anxiety levels associated with the pandemic among adults and children in the UAE. We also examined the association between anxiety levels and demographics, knowledge, beliefs, hygienic practices, coping mechanisms, worry, fear and perceived risk related to COVID-19. This makes our study the first in the UAE to discuss this aspect in the current pandemic.

\section{Methods}

\section{Participants}

A stratified random sample of schools was selected from a list of schools in the UAE retrieved from the EdArabia website [32]. We randomly selected and contacted 17 schools to take part in the study. However, with school closures and the transition to online learning at the time 
of the study, only four schools responded and agreed to distribute the survey link with parents and teachers in their school. Using convenience and snowball sampling, participants were invited to take an online survey using email announcements through participating schools and posts on Facebook, Instagram and WhatsApp. Teachers, parents, and members of the public throughout the UAE, 18 years and older, participated and passed the survey link to friends. Data were collected from 24th March to 15th May, 2020. The survey was administered via the Survey Monkey platform [33], and each response came from a unique IP address to ensure unique entries. The first page explained the research objectives and assured confidentiality. The minimum sample size needed for this cross-sectional study was 385, calculated for an expected prevalence of $50 \%$, margin of error of 5 , and $95 \%$ confidence.

\section{Ethical approval and consent}

The study was approved by the University of Sharjah Ethics Committee (approval number REC-20-03-12-01) and the United Arab Emirates University research ethics review board (ERS_2020_6098) and all research was performed in accordance with regulations of these committees. Participants gave online written consent to participate in the study prior to starting the survey.

\section{Data collection}

A structured questionnaire comprising 32 items was used. Questions were divided into eight domains: demographics, knowledge, beliefs and perceived risk related to COVID-19, health-protective and hygienic behaviors, precautionary measures, worry and fear associated with COVID-19, general health, validated self-reported anxiety screening scales (adults and children) and coping mechanisms. The questionnaire (Appendix 1) was translated into Arabic by a certified translator, and backtranslated to English to ensure accuracy. The final version was piloted among ten members of the general community to ensure clarity and consistency. The questionnaire was sent to a group of ten experts consisting of faculty, teachers, parents, and a mental health expert who reviewed the survey for accuracy, length, clarity and comprehensiveness. Modifications were made to questions and response items based on expert recommendations. The questionnaire took ten minutes to complete.

\section{Demographics}

Information was collected on participants' age, sex, educational level, emirate or country of residence, marital status, number of children, ages and level of schooling, employment status, monthly income and health insurance. Participants indicated if they were parents, a parent and teacher, teachers only or neither parent nor teacher.

Knowledge, beliefs and perceived risks related to COVID-19 Participants were asked to answer "true", "false", or "don't know" on statements related to COVID-19, such as "there is no specific treatment" and "I feel a sense of social responsibility by staying at home". Perceived risk from COVID-19 was assessed on a 4-point Likert scale (very likely to not likely at all) where participants responded to the likelihood of contracting COVID-19, surviving COVID-19 or developing severe illness.

\section{Health-protective practices and hygienic behaviors}

Participants described how often they followed hygienic measures. Responses to seven questions (covering mouth when sneezing/coughing, using hand sanitizer, handwashing, wearing facemasks, avoiding crowded areas, public transport and handshakes) were measured on a 4point Likert scale (always to never). These questions were modified from versions used in studies during MERS-CoV, swine flu and SARS [7, 9, 34, 35]. To categorize hygienic behavior into dichotomous types, a standard median split was performed [36] with a median cut-off of 25 . A value of $\geq 25$ indicated high exhibiting behaviors.

\section{Worry and fear associated with COVID-19}

To assess worry and fear of COVID-19, participants were asked to rate how worried they were on seven questions: Worried about catching COVID-19 myself; Worried about parents catching COVID-19; Worried about child catching COVID-19; Worried about what COVID-19 can do to me health-wise; Worried about social isolation/quarantine; Worried about loss of income; and Worried about transmitting the virus to family and friends. Participants responded on a 5-point Likert scale from extremely worried to not worried at all. Participants were also asked their opinion on public fear associated with COVID-19 on a 5-point Likert scale (strongly agree to strongly disagree) [37]. To categorize worry into dichotomous categories, a standard median split was carried out [36] with a median cutoff of 22 . A value of $\geq 22$ was signified as very worried.

\section{Anxiety}

Anxiety among adults was measured using the generalized anxiety disorder scale (GAD-7) [38] which is a selfreported 7-item validated scale. Participants indicated how often they were bothered during the previous 2 weeks by symptoms of feeling nervous, not being able to stop worrying, worrying about different things, trouble relaxing, restless, irritable and afraid that something awful might happen. Response options were "not at all," 
"several days," "more than half the days," and "nearly every day," scored as $0,1,2$, and 3 . A score of $\geq 10$ identified cases of anxiety with $89 \%$ sensitivity and $82 \%$ specificity, good internal consistency (Cronbach $\alpha=.92$ ) and test-retest reliability (intraclass correlation $=0.83$ ) [38]. Other research established a cutoff of 8 , (sensitivity $77 \%$, specificity $82 \%$ ) as a screener for panic disorder, social anxiety phobia and PTSD [39]. GAD-7 scores were totaled and classified as minimal (0-4), mild (5-9), moderate (10-14) and severe (15-21) [38], and stratified into two groups $(<8$ or $>8)$ as a cut-off for panic disorder and social anxiety phobia [39].

Children's anxiety levels were measured using the emotional symptoms sub-scale from the strengths and difficulties questionnaire (SDQ) [40], which covers emotional symptoms, conduct problems, hyperactivityinattention, peer relationship problems, and prosocial behaviors. It was designed to screen for psychological disorders in children aged 3 to 16 years [29]. The emotional symptoms sub-scale [41] asks parents and teachers questions about symptoms they have witnessed in children: Often complains of headaches, stomach-ache or sickness; Many worries, often seems worried; Often unhappy, down-hearted or tearful; Nervous or clingy in new situations, easily loses confidence; and, Many fears, easily scared. Each item can be marked "not true" (0), "somewhat true" (1) or "certainly true" (2) thereby generating a score of 0-10. A cutoff score of 7 indicates generalized anxiety disorder (sensitivity $75 \%$, specificity $80 \%$ ) and depressive and generalized anxiety disorders (sensitivity 67\%, specificity 81\%) [42]. According to scoring guidelines [43], an abnormal emotional problems score completed by both parents and teachers ranged from 5 to 10 with SDQ $\geq 5$ indicating abnormal emotional problems and a score of 4 indicating borderline problems Validated Arabic translations of both the GAD-7 and SDQ were used for the Arabic translation of the questionnaire $[44,45]$.

To determine the impact of measures to reduce anxiety, participants were asked whether they felt less anxious with the introduction of online learning, airport screening, travel bans, availability of hand sanitizer in public places, cancellation of social events, temporary closure of public places and social isolation. Responses were recorded on a 5-point Likert scale (strongly agree to strongly disagree). To categorize precautionary measures into dichotomous categories, a standard median split was carried out [36] with a median cutoff of 34 . A score of $\geq 34$ indicated high agreement with precautionary measures.

\section{Coping mechanisms}

Participants were asked to indicate on a 4-point Likert scale (always to never) which coping mechanisms they used to reduce anxiety in their children and family. Questions included: openly discussing COVID-19 with children/family, educating children about proper hygiene, assuring children they are safe, limiting children's exposure to news coverage and social media, creating a schedule of learning and fun activities and maintaining regular routine. To categorize coping strategies into dichotomous categories a standard median split was carried out [36] with a median cutoff of 18. A score of $\geq 18$ indicated high coping strategies.

\section{General health}

Participants were asked whether they suffered from chronic disease or had flu-like symptoms over the previous 2 weeks, the treatments for such symptoms, the likelihood of taking a COVID-19 vaccine, whether their children were vaccinated, whether they smoked and if their smoking habits had changed since the outbreak.

\section{Statistical analysis}

Descriptive statistics, including means, medians, frequencies and percentages were used to summarize data and to illustrate participants' demographics and characteristics. The normal distribution of data was verified visually using histograms, boxplots, and quantilequantile plots, and statistically using the KolmogorovSmirnov test. The equality of variances was checked using Levene's test. Chi-square ( $\mathrm{x} 2)$ tests explored associations between participant demographics, knowledge, health protective practices and hygienic behavior, general health, worry and fear, coping mechanisms, and anxiety levels. Statistically significant factors in the chisquare analysis were included in multivariable binary logistic regression models to determine predictors of anxiety levels (GAD-7 score $\geq 8$ ) and emotional problems in children (SDQ score $\geq 5$ ). The automatic selection of predictors in the model was performed by a stepwise backward method with an entry threshold of 0.05 and an exit threshold of 0.1. The adequacy of the models was verified by the Hosmer and Lemeshow test and the specificity of the model by Link Test. The estimates of the strengths of associations were demonstrated by the odds ratio (OR) with a 95\% confidence interval (CI). A twotailed $p<0.05$ was considered statistically significant. Data were analyzed using statistical software $\mathrm{SAS}^{\bullet} 9.3$ [46].

\section{Results}

In total, 2200 people completed the online participant sheet and consent form. Of these, 26 indicated they did not wish to proceed further and 381 completed only the demographic part of the questionnaire before discontinuing. Complete data were analyzed for 1469 participants (68\%). Table 1 summarizes the demographics. 
Table 1 Demographic characteristics by anxiety score (GAD-7 $\geq 8)$ and children emotional SDQ score (SDQ $\geq 5)(N=1469)$

\begin{tabular}{|c|c|c|c|c|c|c|c|c|c|}
\hline \multirow[b]{2}{*}{ Variable } & \multicolumn{3}{|l|}{ Demographics } & \multicolumn{3}{|c|}{ Anxiety GAD-7 Score $(\geq 8)$} & \multicolumn{3}{|c|}{$\begin{array}{l}\text { Reported Children Emotional } \\
\text { SDQ Score }(S D Q \geq 5)\end{array}$} \\
\hline & Category & Frequency (n) & $\%$ & $\%(n)$ & Chi- square $x^{2}$ & $p$-value & $\%(n)$ & Chi-square $x^{2}$ & $p$-value \\
\hline \multirow[t]{2}{*}{ Sex } & Female & 1216 & 82.8 & $51.7(629)$ & 10.16 & $0.001^{*}$ & $16.2(154)$ & 2.83 & 0.093 \\
\hline & Male & 253 & 17.2 & 40.7 (103) & & & $11.5(24)$ & & \\
\hline \multirow[t]{4}{*}{ Relationship to child/ren } & Parent & 893 & 60.8 & $48.2(430)$ & 4.24 & 0.120 & $14.6(130)$ & 25.6 & $<0.001^{*}$ \\
\hline & Teacher only & 106 & 7.2 & $44.3(47)$ & & & $4.7(5)$ & & \\
\hline & $\begin{array}{l}\text { Parent \& } \\
\text { teacher }\end{array}$ & 161 & 11.0 & $55.9(90)$ & & & $26.7(43)$ & & \\
\hline & No children & 299 & 20.4 & $54.2(162)$ & & & 0 & & \\
\hline \multirow[t]{4}{*}{ Age } & $18-24$ & 169 & 11.5 & $59.8(101)$ & 22.27 & $<0.001^{*}$ & $8.7(2)$ & 3.44 & 0.329 \\
\hline & $25-44$ & 907 & 61.7 & $51.0(463)$ & & & $14.7(115)$ & & \\
\hline & $45-64$ & 381 & 25.9 & $43.6(166)$ & & & $17.4(61)$ & & \\
\hline & $65+$ & 12 & 0.8 & $16.7(2)$ & & & 0 & & \\
\hline \multirow[t]{5}{*}{ Education } & Primary & 11 & 0.7 & $36.4(4)$ & 3.14 & 0.534 & $11.1(1)$ & 1.76 & 0.779 \\
\hline & $\begin{array}{l}\text { Lower } \\
\text { secondary }\end{array}$ & 10 & 0.7 & $30.0(3)$ & & & $25.0(2)$ & & \\
\hline & $\begin{array}{l}\text { Higher } \\
\text { secondary }\end{array}$ & 137 & 9.3 & $53.3(73)$ & & & $18.2(18)$ & & \\
\hline & $\begin{array}{l}\text { Bachelor } \\
\text { degree }\end{array}$ & 746 & 50.8 & $50.1(374)$ & & & $14.4(79)$ & & \\
\hline & Post-graduate & 565 & 38.5 & $49.2(278)$ & & & $15.8(78)$ & & \\
\hline \multirow[t]{2}{*}{ Country of Residence } & $\begin{array}{l}\text { Outside the } \\
\text { UAE }\end{array}$ & 400 & 27.2 & 49.0 (196) & 0.15 & 0.697 & $15.6(51)$ & 0.02 & 0.882 \\
\hline & Inside the UAE & 1069 & 72.8 & $50.1(536)$ & & & $15.2(127)$ & & \\
\hline \multirow[t]{3}{*}{ Employment } & Employed & 927 & 63.1 & $48.8(452)$ & 2.00 & 0.372 & $15.6(122)$ & 1.08 & 0.583 \\
\hline & Not employed & 319 & 21.7 & $53.3(170)$ & & & $12.9(22)$ & & \\
\hline & Home duties & 223 & 15.2 & $49.3(110)$ & & & $16.6(34)$ & & \\
\hline \multirow[t]{6}{*}{ Monthly Salary } & Other & 192 & 13.1 & $46.4(89)$ & 5.19 & 0.393 & $15.2(25)$ & 9.90 & 0.079 \\
\hline & less than 5000 & 161 & 11.0 & $55.9(90)$ & & & $12.4(13)$ & & \\
\hline & 5000-9999 & 163 & 11.1 & $54.0(88)$ & & & $20.2(23)$ & & \\
\hline & $10,000-19,999$ & 282 & 19.2 & 48.9 (138) & & & $15.8(35)$ & & \\
\hline & $20,000-39,000$ & 413 & 28.1 & $49.6(205)$ & & & $18.1(60)$ & & \\
\hline & $40,000+$ & 258 & 17.6 & $47.3(122)$ & & & $9.9(22)$ & & \\
\hline \multirow[t]{3}{*}{ Insurance } & Other & 21 & 1.4 & $47.6(10)$ & 0.634 & 0.729 & $15.4(2)$ & 4.13 & 0.126 \\
\hline & No & 226 & 15.4 & $52.2(118)$ & & & $10.1(17)$ & & \\
\hline & Yes & 1222 & 83.2 & $49.4(604)$ & & & $16.2(159)$ & & \\
\hline \multirow[t]{4}{*}{ Marital Status } & Single & 287 & 19.5 & $55.7(160)$ & 7.27 & 0.064 & $4.2(3)$ & 11.9 & $0.008^{*}$ \\
\hline & Married & 1094 & 74.5 & $47.8(523)$ & & & $15.5(157)$ & & \\
\hline & $\begin{array}{l}\text { Divorced/ } \\
\text { Separated }\end{array}$ & 72 & 4.9 & $56.9(41)$ & & & $25.4(16)$ & & \\
\hline & Widowed & 16 & 1.1 & $50.0(8)$ & & & $14.3(2)$ & & \\
\hline \multirow[t]{2}{*}{ Do you have children? } & Yes & 1111 & 75.6 & $49.1(545)$ & 1.10 & 0.296 & & & \\
\hline & No & 358 & 24.4 & $52.2(187)$ & & & & & \\
\hline \multirow[t]{3}{*}{ Number of children } & $1-2$ children & 517 & 35.2 & $49.7(257)$ & 4.85 & 0.089 & $16.6(80)$ & 0.070 & 0.966 \\
\hline & 3-4 children & 473 & 32.2 & $50.5(239)$ & & & $16.0(73)$ & & \\
\hline & $4+$ children & 119 & 8.1 & $39.5(47)$ & & & 16.5(19) & & \\
\hline Age category of children & Infants and & 269 & 18.3 & $52.4(141)$ & 0.88 & 0.348 & $16.2(154)$ & 0.167 & 0.683 \\
\hline
\end{tabular}


Table 1 Demographic characteristics by anxiety score (GAD-7 $\geq 8)$ and children emotional SDQ score (SDQ $\geq 5)(N=1469)$ (Continued)

\begin{tabular}{|c|c|c|c|c|c|c|c|c|c|}
\hline \multirow[b]{2}{*}{ Variable } & \multicolumn{3}{|l|}{ Demographics } & \multicolumn{3}{|c|}{ Anxiety GAD-7 Score $(\geq 8)$} & \multicolumn{3}{|c|}{$\begin{array}{l}\text { Reported Children Emotional } \\
\text { SDQ Score }(S D Q \geq 5)\end{array}$} \\
\hline & Category & Frequency (n) & $\%$ & $\%(n)$ & Chi- square $x^{2}$ & $p$-value & $\%(n)$ & Chi-square $x^{2}$ & $p$-value \\
\hline & Toddlers & & & & & & & & \\
\hline & Preschoolers & 325 & 22.1 & $53.8(175)$ & 2.69 & 0.101 & $11.5(24)$ & 0.085 & 0.770 \\
\hline & School Age & 713 & 48.5 & $50.5(360)$ & 0.24 & 0.623 & $14.6(130)$ & 5.93 & $0.015^{*}$ \\
\hline & Adolescents & 432 & 29.4 & $48.6(210)$ & 0.36 & 0.547 & $17.5(121)$ & 8.83 & $0.003^{*}$ \\
\hline & Young Adults & 254 & 17.3 & $42.5(108)$ & 6.56 & $0.010^{*}$ & $19.6(81)$ & 1.53 & 0.216 \\
\hline \multirow[t]{6}{*}{ Children attending school } & $\begin{array}{l}\text { Children don't } \\
\text { go to school }\end{array}$ & 183 & 12.5 & $55.7(102)$ & 2.92 & 0.088 & $13.6(22)$ & 0.45 & 0.502 \\
\hline & Childcare & 205 & 14.0 & $50.2(103)$ & 0.01 & 0.898 & $16.4(32)$ & 0.20 & 0.651 \\
\hline & Primary & 668 & 45.5 & $52.4(350)$ & 3.23 & 0.073 & $16.8(109)$ & 2.39 & 0.123 \\
\hline & $\begin{array}{l}\text { Lower } \\
\text { secondary }\end{array}$ & 400 & 27.2 & $49(196)$ & 0.15 & 0.697 & $21.4(82)$ & 16.2 & $<0.001^{*}$ \\
\hline & $\begin{array}{l}\text { Higher } \\
\text { Secondary }\end{array}$ & 320 & 21.8 & $45.6(146)$ & 2.89 & 0.089 & $20.5(63)$ & 8.61 & $0.003^{*}$ \\
\hline & University & 258 & 17.6 & $42.6(110)$ & 6.48 & $0.011^{*}$ & $17.4(40)$ & 0.92 & 0.336 \\
\hline \multirow[t]{2}{*}{ Likely to vaccinate self } & No & 383 & 26.1 & $41.3(158)$ & 20.05 & $<0.001^{*}$ & & & \\
\hline & Yes & 1050 & 71.5 & $53.2(559)$ & & & & & \\
\hline \multirow[t]{2}{*}{ Likely to vaccinate children } & No & 314 & 21.4 & $41.7(131)$ & 20.71 & $0.001^{*}$ & & & \\
\hline & Yes & 872 & 59.4 & $52.4(457)$ & & & & & \\
\hline \multirow{8}{*}{$\begin{array}{l}\text { Do you have any of the } \\
\text { following medical Conditions } \\
\text { (Yes) }\end{array}$} & Diabetes & 75 & 5.1 & $53.3(40)$ & 0.39 & 0.533 & & & \\
\hline & Heart Problems & 36 & 2.5 & $58.3(21)$ & 1.07 & 0.301 & & & \\
\hline & $\begin{array}{l}\text { High Blood } \\
\text { Pressure }\end{array}$ & 133 & 9.1 & $51.9(69)$ & 0.25 & 0.620 & & & \\
\hline & Dyslipidemia & 45 & 3.1 & $48.9(22)$ & 0.89 & 0.898 & & & \\
\hline & Asthma & 127 & 8.6 & $62.2(79)$ & 8.52 & $0.004^{*}$ & & & \\
\hline & $\begin{array}{l}\text { Respiratory } \\
\text { problems }\end{array}$ & 47 & 3.2 & $53.2(25)$ & 0.64 & 0.639 & & & \\
\hline & Cancer & 9 & 0.6 & $44.4(4)$ & 0.75 & 0.746 & & & \\
\hline & $\begin{array}{l}\text { Other medical } \\
\text { conditions }\end{array}$ & 128 & 8.7 & $50.8(65)$ & 0.82 & 0.822 & & & \\
\hline \multirow{10}{*}{$\begin{array}{l}\text { Have you experienced any of the } \\
\text { following symptoms (Yes) }\end{array}$} & Headaches & 381 & 25.9 & $56.7(216)$ & 9.69 & $0.002^{*}$ & & & \\
\hline & Fever & 105 & 7.1 & $56.2(59)$ & 1.83 & 0.176 & & & \\
\hline & Cough & 235 & 16.0 & $51.1(120)$ & 0.17 & 0.680 & & & \\
\hline & $\begin{array}{l}\text { Difficulty } \\
\text { breathing }\end{array}$ & 37 & 2.5 & $51.4(19)$ & 0.03 & 0.851 & & & \\
\hline & Sore throat & 256 & 17.4 & $59.8(153)$ & 12.2 & $<0.001^{*}$ & & & \\
\hline & Myalgia & 49 & 3.3 & $59.2(29)$ & 1.77 & 0.183 & & & \\
\hline & Dizziness & 73 & 5.0 & $63(46)$ & 5.34 & $0.021^{*}$ & & & \\
\hline & Runny nose & 225 & 15.3 & $53.8(121)$ & 1.66 & 0.198 & & & \\
\hline & Diarrhea & 100 & 6.8 & $50(50)$ & 0.001 & 0.972 & & & \\
\hline & $\begin{array}{l}\text { Other } \\
\text { Symptoms }\end{array}$ & 18 & 1.2 & $50(9)$ & $<0.001$ & 0.988 & & & \\
\hline \multirow{3}{*}{$\begin{array}{l}\text { What measures have you taken } \\
\text { to treat your symptoms }\end{array}$} & Vitamin C & 720 & 49.0 & $53.5(385)$ & 7.49 & $0.006^{*}$ & & & \\
\hline & $\begin{array}{l}\text { Flu } \\
\text { medications }\end{array}$ & 92 & 6.3 & $53.3(49)$ & 0.46 & 0.497 & & & \\
\hline & Anti- & 139 & 9.5 & $62.6(87)$ & 1.00 & $0.002^{*}$ & & & \\
\hline
\end{tabular}


Table 1 Demographic characteristics by anxiety score (GAD-7 $\geq 8)$ and children emotional SDQ score (SDQ $\geq 5)(N=1469)$ (Continued)

\begin{tabular}{|c|c|c|c|c|c|c|c|c|c|}
\hline \multirow[b]{2}{*}{ Variable } & \multicolumn{3}{|l|}{ Demographics } & \multicolumn{3}{|c|}{ Anxiety GAD-7 Score $(\geq 8)$} & \multicolumn{3}{|c|}{$\begin{array}{l}\text { Reported Children Emotional } \\
\text { SDQ Score }(S D Q \geq 5)\end{array}$} \\
\hline & Category & Frequency (n) & $\%$ & $\%(n)$ & Chi- square $x^{2}$ & $p$-value & $\%(n)$ & Chi-square $x^{2}$ & $p$-value \\
\hline & $\begin{array}{l}\text { inflammatory } \\
\text { drugs }\end{array}$ & & & & & & & & \\
\hline & $\begin{array}{l}\text { Analgesics anti- } \\
\text { pyretic }\end{array}$ & 345 & 23.5 & $58.6(202)$ & 13.7 & $<0.001^{*}$ & & & \\
\hline & Oral Steroids & 17 & 1.2 & $58.8(10)$ & 0.55 & 0.456 & & & \\
\hline & $\begin{array}{l}\text { Herbal } \\
\text { remedies }\end{array}$ & 443 & 30.2 & $51.2(227)$ & 0.51 & 0.477 & & & \\
\hline \multirow{3}{*}{$\begin{array}{l}\text { My child/ren are up to date with } \\
\text { their vaccines }\end{array}$} & No & 81 & 5.5 & $45.7(37)$ & 1.49 & 0.476 & & & \\
\hline & Yes & 1029 & 70.0 & $49.5(509)$ & & & & & \\
\hline & $\begin{array}{l}\text { I don't have } \\
\text { children }\end{array}$ & 334 & 22.7 & $52.4(175)$ & & & & & \\
\hline \multirow[t]{3}{*}{ Smoking } & No & 1196 & 81.4 & $47.3(566)$ & 19.01 & $<0.001^{*}$ & & & \\
\hline & Yes & 195 & 13.3 & $62.1(121)$ & & & & & \\
\hline & $\begin{array}{l}\text { I used to } \\
\text { smoke but quit }\end{array}$ & 53 & 3.6 & $64.2(34)$ & & & & & \\
\hline \multirow[t]{4}{*}{ Smoke type } & Cigarettes & 111 & 7.6 & $58.6(65)$ & 3.66 & 0.056 & & & \\
\hline & Shisha & 83 & 5.7 & $65.1(54)$ & 8.16 & $0.004^{*}$ & & & \\
\hline & Midwakh & 8 & 0.5 & $50(4)$ & 0.01 & 0.992 & & & \\
\hline & Vaping & 22 & 1.5 & $59.1(13)$ & 0.76 & 0.381 & & & \\
\hline \multirow{2}{*}{$\begin{array}{l}\text { Smoking changed During COVID- } \\
19\end{array}$} & Yes & 201 & 13.7 & $58.7(118)$ & 7.73 & $0.005^{*}$ & & & \\
\hline & No & 1228 & 83.6 & $48.1(591)$ & & & & & \\
\hline \multirow[t]{2}{*}{ Changes made to smoking } & $\begin{array}{l}\text { Stopped/ } \\
\text { Decreased }\end{array}$ & 73 & 5 & $54.4(49)$ & 2.80 & 0.422 & & & \\
\hline & $\begin{array}{l}\text { Started/ } \\
\text { Increased }\end{array}$ & 18 & 1.2 & $14.7(13)$ & & & & & \\
\hline \multirow[t]{4}{*}{ Anxiety (GAD-7) levels } & Minimal & 447 & 30.4 & - & & & $3.9(14)$ & 122.19 & $<0.001^{*}$ \\
\hline & Mild & 465 & 32.7 & - & & & $9.6(35)$ & & \\
\hline & Moderate & 296 & 20.2 & - & & & $24.5(58)$ & & \\
\hline & Severe & 261 & 17.8 & - & & & $35.3(71)$ & & \\
\hline \multirow[t]{4}{*}{ Difficulty getting things done } & $\begin{array}{l}\text { Not difficult at } \\
\text { all }\end{array}$ & 450 & 30.6 & 16.2(73) & 392.41 & $<0.001^{*}$ & $4.5(16)$ & 738.01 & $<0.001^{*}$ \\
\hline & Somewhat & 747 & 50.9 & $55.3(413)$ & & & $14.6(87)$ & & \\
\hline & Very & 186 & 12.7 & $88.7(165)$ & & & $36.2(55)$ & & \\
\hline & Extremely & 86 & 5.9 & $94.2(81)$ & & & $35.7(20)$ & & \\
\hline \multirow[t]{2}{*}{ Anxiety GAD class $(\geq 8)$} & Mild-Minimal & 737 & 50.2 & - & & & 25.4(144) & 86.20 & $<0.001^{*}$ \\
\hline & High & 732 & 49.8 & - & & & 5.7 (34) & & \\
\hline \multirow[t]{2}{*}{ SDQ class $(\geq 5)$} & Normal & 982 & 84.7 & $43.1(423)$ & 86.3 & $<0.001^{*}$ & & & \\
\hline & Abnormal & 178 & 15.3 & $80.9(144)$ & & & & & \\
\hline
\end{tabular}

*Significant at $p<0.05$

Participants were primarily female (82.8\%), 25 to 44 years of age (61.7\%) and resided in the UAE (72.8\%). Over half of our population held a bachelor's degree (50.8\%) and were employed (63.1\%). Seventy five percent of participants were married and had children (75.6\%), with the majority having 1-2 children
(35.2\%). The most commonly reported medical conditions were high blood pressure (9.1\%) and asthma (8.6\%). Headaches (25.9\%) were the most commonly reported COVID-19 symptom and almost half of participants indicated they used vitamin $C$ to treat their symptoms. Whilst most participants reported they did 
not smoke, $13.7 \%$ stated they had changed their smoking habits since the COVID-19 outbreak. Most indicated they would get vaccinated (71.5\%) and have their children vaccinated (59.4\%) against COVID-19. The majority indicated their children were current with vaccinations (85\%); however, we found a significant association between those who reported their children were not current with vaccinations (53\%) and their intention to not vaccinate their children against COVID-19.

\section{Anxiety levels (GAD-7 score and SDQ score)}

Almost three quarters (71\%) of our adult population reported anxiety, and $38 \%$ had moderate to severe anxiety. When we categorized anxiety by high and low based on the GAD-7 cutoff of 8 , half of our participants (49.8\%) reported higher levels of anxiety. Females (51.7\%) and participants between the ages of 18 and 24 years (59.8\%) reported greater anxiety. Higher anxiety levels were reported amongst participants with higher levels of education, but differences were not significant. More than half of participants who indicated they were likely to be vaccinated against COVID-19 were more anxious. More than half of parents who indicated they were likely to vaccinate their children with the COVID-19 vaccine had higher anxiety levels. Higher levels of anxiety were reported by asthmatics and those who had experienced headaches, sore throat or dizziness. Highly anxious participants were more likely to take vitamin C (53.5\%), anti-inflammatory drugs (62.6\%) and analgesics (58.6\%). Participants who had quit smoking had higher anxiety levels. (Table 1).

Parents reported abnormal emotional problems in just over $15 \%$ of children. If borderline SDQ scores are also taken into consideration, a quarter of children $(24.6 \%)$ had reported emotional problems. The highest percentage of reported emotional problems for children was in participants who were both parents and teachers (26.7\%) compared to parents only $(14.6 \%)$ or teachers only (4.7\%). Participants who were divorced/separated reported higher SDQ scores in their children (25.4\%), compared to those who were married (15.5\%) and school-aged children or adolescents showed significant differences in emotional problems compared to children who were not $(17.5 \%)$ and (19.6\%) respectively. Emotional problems were also more commonly reported among children attending lower secondary and higher secondary schools. Parents reporting moderate to severe anxiety levels in the GAD-7, also reported higher SDQ scores in their children. A higher percentage of parents of children with emotional problems also reported they found it "Very or extremely" difficult to get things done (36.1\%) (Table 1).

\section{Knowledge, beliefs, hygienic behavior and anxiety}

Overall, participants showed a good knowledge of COVID-19 and the majority were aware that there was no treatment. Participants (83\%) perceived a likelihood of catching COVID-19 with almost half reporting higher levels of anxiety. More than half who believed they would develop severe illness upon contracting the virus reported higher levels of anxiety (Table 2). Almost all participants had made significant changes in their hygienic behavior since the pandemic and reported increased use of hand sanitizer (87\%), washing hands (99\%), wearing facemasks (47\%), and avoiding crowds (96\%), public transportation (98\%) and handshaking (95\%). Significantly higher levels of anxiety were reported amongst participants who always used hand sanitizers and face masks. When behavioral changes were further categorized into two groups, participants who always practiced hygienic behaviors, reported significantly higher levels of anxiety (Table 3).

\section{Precautionary measures and anxiety}

Although most participants felt less anxious with the government's precautionary measures, participants who disagreed reported higher GAD-7 scores for online learning, cancellation of social events and social isolation. Participants who agreed with overall precautionary measures showed significantly less anxiety than those who disagreed (Table 4).

\section{Worry, fear and anxiety}

The majority of participants felt public fear was justified. However, we found greater anxiety among those who believed that fear caused unnecessary absences from work and school. Whilst most participants worried about contracting COVID-19, the majority were more worried about their parents (75\%) or children (65.5\%) catching COVID-19 or transmitting it to someone else if they caught it (64.5\%). Significantly higher GAD-7 scores were found among all participants who agreed they were worried about catching COVID-19, their parents or children catching it, about what would happen if they caught it, about being in social isolation, loss of income and transmitting it to others. When we categorized worry into two groups, "low levels of worry" and "high levels of worry", we found significantly higher levels of anxiety among participants who reported being very worried (Table 5). Worry in parents was associated with SDQ score, and parents with higher scores reported more emotional problems in their children. Parents who were very worried reported significantly higher SDQ scores for their children (Table 5).

Among participants with children, most were utilizing effective coping strategies; however, higher anxiety was reported among participants who always openly discussed 
COVID-19 with their family (51.4\%), compared to those who never did (33.3\%). Participants who always educated their children about proper protective measures $(50.3 \%)$ or limited news exposure (53.4\%) had higher anxiety levels compared to those who never did these things $(23.1 \%)$ and $(41 \%)$ respectively. When we categorized these strategies into two groups low use and high use of coping strategies, we found no differences in anxiety levels based on GAD-7 score. For SDQ scores reported by parents, we found more emotional problems in children whose parents/teachers discussed COVID-19 with them (17.5\%) and among those who educated their children about personal protective measures (20.9\%). Parents who always utilized coping strategies for dealing with COVID-19, reported greater emotional problems in their children than parents who used fewer coping strategies (Table 6).

To estimate the probability of anxiety levels among participants in our study, two multivariable logistic regressions were conducted--one with the GAD-7 score $\geq$ 8 as a measure of adult anxiety and the other with the SDQ score $\geq 5$ for anxiety and emotional problems in children. In the first model, the effects of adults sex, adults age, age of children, adults perception of fear, perception of likelihood to contract COVID-19 and to develop severe disease, headaches, sore throat, asthma, measures taken for symptoms, smoking, and changed smoking habits, likelihood of vaccination for self and children, hygienic behavior category, precautionary measures category and worry category were modelled. The omnibus model for logistic regression analysis was statistically significant $x^{2}(40, N=1469)=276.2, p \leq 0.001$. The model explained 28\% (Nagelkerke $\mathrm{R}^{2}$ ) of the variance in anxiety levels. Hosmer and Lemeshow test results confirmed the model was a good fit for the data $X^{2}(8, N=1469)=7.16, p=0.519$ (Table 7). Females had 1.91 times higher odds of reporting anxiety than males, and participants who believed that fear was justified were six times more anxious than those who disagreed. Higher levels of worry were also associated with increased anxiety levels. Participants who said they would take the COVID-19 vaccine were 1.57 times more likely to report higher anxiety, however, likelihood to vaccinate children did not influence anxiety $(p=0.158)$. The odds of higher anxiety were larger among participants who smoked, took vitamin $\mathrm{C}$ for symptoms and reported sore throat (Table 7).

In the second model, with $\mathrm{SDQ} \geq 5$ as a measure of anxiety in children, the effects of relationship of the adult completing the survey to the child, adult's marital status, child's age (school-aged or adolescent),, educational level of child (lower secondary and higher secondary), parental coping strategies, worry, parental anxiety level and parental reports of difficulty getting things done were modelled. The omnibus model for logistic regression analysis was significant $\chi^{2}(17, N=1160)=$ 185.90, $p \leq 0.001$ and explained 26\% (Nagelkerke $\mathrm{R}^{2}$ ) of the variance in children's anxiety levels. Hosmer and Lemeshow test results confirmed the model was a good fit $X^{2}(7, N=1160)=11.99, p=0.101$ (Table 7). Participants who were both parents and teachers were five times more likely to report emotional problems in children mostly in adolescents in lower and secondary school. Parents with severe anxiety levels were seven times more likely to report emotional problems in their

Table 2 Prevalence of GAD-7 score $\geq 8$ by knowledge and beliefs related to COVID-19 ( $N=1469)$

\begin{tabular}{|c|c|c|c|c|c|c|}
\hline Characteristics & Category & Frequency $(n)$ & $\%$ & $\begin{array}{l}\text { Anxiety GAD-7 Score }(\geq 8) \\
\%(n)\end{array}$ & Chi Square $x^{2}$ & $p$-value \\
\hline \multirow[t]{3}{*}{ No Treatment Available for COVID-19 } & Don't know & 187 & 12.7 & $54.5(102)$ & 2.68 & 0.262 \\
\hline & False & 180 & 12.3 & $46.1(83)$ & & \\
\hline & True & 1102 & 75.0 & $49.6(547)$ & & \\
\hline \multirow[t]{3}{*}{ I feel a Sense of Social Responsibility } & Don't know & 19 & 1.3 & $36.8(7)$ & 1.36 & 0.505 \\
\hline & False & 15 & 1.0 & $46.7(7)$ & & \\
\hline & True & 1435 & 97.7 & $50(718)$ & & \\
\hline \multirow[t]{3}{*}{ There is likelihood of catching COVID-19 } & Don't know & 100 & 6.8 & $40.0(40)$ & 7.26 & $0.026^{*}$ \\
\hline & Not likely & 155 & 10.6 & $43.9(68)$ & & \\
\hline & Likely & 1214 & 82.6 & $51.4(624)$ & & \\
\hline \multirow[t]{3}{*}{ There is likelihood of surviving COVID-19 } & Don't know & 113 & 7.7 & $54.0(61)$ & 3.14 & 0.208 \\
\hline & Not likely & 50 & 3.4 & $60.0(30)$ & & \\
\hline & Likely & 1306 & 88.9 & $49.1(64)$ & & \\
\hline \multirow[t]{3}{*}{ There is likelihood I will develop severe illness } & Don't know & 199 & 13.5 & $48.2(96)$ & 13.56 & $0.001^{*}$ \\
\hline & Not likely & 433 & 29.5 & $43.0(186)$ & & \\
\hline & Likely & 837 & 57.0 & $49.8(732)$ & & \\
\hline
\end{tabular}


Table 3 Prevalence of GAD-7 score $\geq 8$ by Hygiene behavior changes taken $(n=1469)$

\begin{tabular}{|c|c|c|c|c|c|c|}
\hline Characteristics & Category & $\begin{array}{l}\text { Frequency } \\
\text { (n) }\end{array}$ & $\%$ & $\begin{array}{l}\text { Anxiety GAD-7 Score } \\
(\geq 8) \%(n)\end{array}$ & $\begin{array}{l}\text { Chi-Square } \\
x^{2}\end{array}$ & $\begin{array}{l}p- \\
\text { value }\end{array}$ \\
\hline \multirow[t]{3}{*}{ Cover mouth } & Never & 13 & 0.9 & $46.2(6)$ & 3.03 & 0.219 \\
\hline & Occasionally & 43 & 2.9 & $62.8(27)$ & & \\
\hline & Most of the time /Always & 1413 & 96.2 & $49.4(699)$ & & \\
\hline \multirow[t]{3}{*}{ Use hand sanitizer } & Never & 26 & 1.8 & $26.9(7)$ & 10.90 & $0.004^{*}$ \\
\hline & Occasionally & 163 & 11.1 & $41.7(68)$ & & \\
\hline & Most of the time /Always & 1280 & 87.1 & $51.3(657)$ & & \\
\hline \multirow[t]{3}{*}{ Washing hands } & Never & 2 & 0.1 & $50.0(1)$ & 1.13 & 0.569 \\
\hline & Occasionally & 14 & 1.0 & $35.7(5)$ & & \\
\hline & Most of the time /Always & 1453 & 98.9 & $50.0(726)$ & & \\
\hline \multirow[t]{3}{*}{ Face mask } & Never & 374 & 25.5 & $48.9(183)$ & 8.84 & $0.012^{*}$ \\
\hline & Occasionally & 408 & 27.8 & $44.4(181)$ & & \\
\hline & Most of the time /Always & 687 & 46.8 & $53.6(368)$ & & \\
\hline \multirow[t]{3}{*}{ Avoid crowds } & Never & 6 & 0.4 & $50.0(3)$ & 0.25 & 0.882 \\
\hline & Occasionally & 60 & 4.1 & $46.7(28)$ & & \\
\hline & Most of the time /Always & 1403 & 95.5 & $50(701)$ & & \\
\hline \multirow[t]{3}{*}{ Avoid public transport } & Never & 14 & 1.0 & $50.0(7)$ & 0.17 & 0.918 \\
\hline & Occasionally & 22 & 1.5 & $45.5(10)$ & & \\
\hline & Most of the time /Always & 1433 & 97.5 & $49.9(715)$ & & \\
\hline \multirow[t]{3}{*}{ Avoid handshaking } & Never & 12 & 0.8 & $66.7(8)$ & 1.59 & 0.451 \\
\hline & Occasionally & 62 & 4.2 & $46.8(29)$ & & \\
\hline & Most of the time /Always & 1395 & 94.9 & $49.8(695)$ & & \\
\hline \multirow[t]{2}{*}{$\begin{array}{l}\text { Behavioral changes total } \\
\text { Category }\end{array}$} & $\begin{array}{l}\text { Occasionally exhibiting behavior } \\
\text { changes }\end{array}$ & 604 & 41.1 & $45.4(274)$ & 8.18 & $<0.004^{*}$ \\
\hline & Always exhibiting behavior changes & 865 & 58.9 & $53.0(458)$ & & \\
\hline
\end{tabular}

"Significant at $p<0.05$

children. Parental reports of "finding it very difficult to do work, to do things at home and to get along with other people" were a strong predictor of emotional problems in children (Table 7).

\section{Discussion}

This study revealed that the pandemic has had a significant impact on the mental health and well-being of the UAE population with the majority of adult participants reporting moderate to severe anxiety. This was most prevalent among women which is consistent with other research showing higher prevalence of anxiety among females compared to males [47-49]. Female anxiety during COVID-19 may be exacerbated by socio-cultural norms and gender-role expectations particularly with the added responsibility of home schooling, work commitments, social isolation and increased concern for family and loved ones. We also found that government measures to contain the virus were correlated with lower levels of anxiety. However, higher levels of anxiety were reported among those who had concerns about online learning which could be due to the disruption caused in their children's education and examinations. Airport closures, screenings and travel bans were also found to be major triggers for anxiety which could be explained by the UAE being a popular travel hub and home to over seven million expatriates. The potential loss of jobs, financial insecurity, suspension of work visas, inability to travel to family and loved ones and overall loss of connection with the world are significant causes of worry [50-52]. Greater worry in our study was correlated with higher GAD-7 scores for concerns over parents' and children's health, fears of bringing infection home from the workplace and loss of income if infected with COVID-19. Parental levels of worry were associated with emotional problems in children, but further analysis showed lower correlation.

Perceptions of greater risk corresponded to increased anxiety. Participants in our study perceived a high risk of COVID-19 contagion and if infected, they perceived high risk of developing severe disease. These findings contradicted research conducted in China during the early stages of the pandemic where participants reported lower perceived likelihood of contracting COVID-19, 
Table 4 Prevalence of GAD-7 score $\geq 8$ by opinions on precautionary measures taken $(N=1469)$

\begin{tabular}{|c|c|c|c|c|c|c|}
\hline Characteristics & Category & $\begin{array}{l}\text { Frequency } \\
\text { (n) }\end{array}$ & $\%$ & $\begin{array}{l}\text { Anxiety GAD-7 Score } \\
(\geq 8) \\
\%(n)\end{array}$ & $\begin{array}{l}\text { Chi Square } \\
x^{2}\end{array}$ & $p$-value \\
\hline \multicolumn{7}{|c|}{ I feel that my levels of anxiety have reduced with the introduction of the following precautionary measures } \\
\hline \multirow{3}{*}{$\begin{array}{l}\text { Online learning at educational } \\
\text { institutions }\end{array}$} & Strongly disagree/Disagree & 220 & 15.0 & $65.0(143)$ & 36.55 & $<0.001^{*}$ \\
\hline & Neutral & 238 & 16.2 & $57.6(137)$ & & \\
\hline & Strongly agree/Agree & 1011 & 68.8 & $44.7(452)$ & & \\
\hline \multirow[t]{3}{*}{ Airport screening } & Strongly disagree/Disagree & 67 & 4.6 & $61.2(41)$ & 14.14 & $0.001^{*}$ \\
\hline & Neutral & 136 & 9.3 & $62.5(85)$ & & \\
\hline & Strongly agree/ Agree & 1266 & 86.2 & $47.9(606)$ & & \\
\hline \multirow[t]{3}{*}{ Travel bans } & Strongly disagree/Disagree & 65 & 4.4 & $55.4(36)$ & 11.11 & $0.004^{*}$ \\
\hline & Neutral & 79 & 5.4 & $67.1(53)$ & & \\
\hline & Strongly agree/Agree & 1325 & 90.2 & $48.5(643)$ & & \\
\hline \multirow[t]{3}{*}{ Hand sanitizers in public spaces } & Strongly disagree/ Disagree & 33 & 2.2 & $51.5(17)$ & 2.31 & 0.315 \\
\hline & Neutral & 98 & 6.7 & $57.1(56)$ & & \\
\hline & Strongly agree/ Agree & 1338 & 91.1 & $49.3(659)$ & & \\
\hline \multirow[t]{3}{*}{ Cancellation of social events } & Strongly disagree/Disagree & 34 & 2.3 & $61.8(21)$ & 7.59 & $0.022^{*}$ \\
\hline & Neutral & 50 & 3.4 & $66.0(33)$ & & \\
\hline & Strongly agree /Agree & 1385 & 94.3 & $49.0(678)$ & & \\
\hline \multirow[t]{3}{*}{ Temporary closure of public places } & Strongly disagree/Disagree & 47 & 3.2 & $51.1(24)$ & 1.76 & 0.415 \\
\hline & Neutral & 51 & 3.5 & $58.8(30)$ & & \\
\hline & Strongly agree/Agree & 1371 & 93.3 & 49.5 (678) & & \\
\hline \multirow[t]{3}{*}{ Social isolation } & Strongly disagree /Disagree & 49 & 3.3 & $61.2(30)$ & 7.26 & $0.026^{*}$ \\
\hline & Neutral & 82 & 5.6 & $61.0(50)$ & & \\
\hline & Strongly agree/Agree & 1338 & 91.1 & $48.7(652)$ & & \\
\hline \multirow[t]{2}{*}{ Precautionary measures category } & $\begin{array}{l}\text { Disagree with precautionary } \\
\text { measures }\end{array}$ & 605 & 41.2 & $54.9(332)$ & 10.48 & $0.001^{*}$ \\
\hline & $\begin{array}{l}\text { Agree with precautionary } \\
\text { measures }\end{array}$ & 864 & 58.8 & $46.3(400)$ & & \\
\hline
\end{tabular}

"Significant at $p<0.05$

which was associated with lower stress [11]. High-risk perception among participants in our study could also explain the high compliance of protective and hygienic behaviors such as handwashing and social distancing. Earlier research indicates that people who were more anxious about contracting COVID-19 were also more engaged in regular hand hygiene and social distancing behaviors [53, 54]. In our study, the majority who had higher GAD-7 scores reported wearing masks and using hand sanitizers. Pre-existing health conditions also create a sense of panic and concern. As demonstrated in our study, those with health conditions like asthma were more likely to feel concern because of probability of infection [55]. Sore throat, taking vitamin $\mathrm{C}$ and smoking remained significant predictors of anxiety levels among participants upon further analysis. Smoking has been associated with adverse COVID-19 prognosis and smokers are at greater risk of developing severe COVID-19 [5658].

The majority of our study population intended to take the COVID-19 vaccine when available and to vaccinate their children. Participants who reported higher anxiety were more likely to vaccinate, although a relatively large percentage said they would not take the vaccine. This is similar to a recent study in France [59] and a local study showing $12 \%$ vaccine hesitancy among the UAE population [60]. Hesitancy about the vaccine was mainly related to safety and political concerns $[59,60]$. This highlights the need for governments to publicize the measures taken to ensure vaccine safety.

The psychological impact of COVID-19 on children in the UAE was assessed for the first time in our study. We found high prevalence of parent reported emotional and anxiety problems and when borderline 
Table 5 Worry about COVID-19 by GAD-7 score $\geq 8$ and reported Child SDQ score $\geq 5(N=1469)$

\begin{tabular}{|c|c|c|c|c|c|c|c|c|c|}
\hline \multirow[b]{2}{*}{ Characteristics } & \multirow[b]{2}{*}{ Category } & \multirow[b]{2}{*}{ Frequency (n) } & \multirow[b]{2}{*}{$\%$} & \multicolumn{3}{|c|}{ Anxiety GAD-7 Score $(\geq 8)$} & \multicolumn{3}{|c|}{$\begin{array}{l}\text { Reported Children Emotional } \\
\text { SDQ Score }(S D Q \geq 5)\end{array}$} \\
\hline & & & & $\%(n)$ & Chi-Square $x^{2}$ & p-value & $\%(\mathrm{n})$ & Chi-square $x^{2}$ & $p$-value \\
\hline \multirow[t]{3}{*}{$\begin{array}{l}\text { I believe the public fear is } \\
\text { justifiable }\end{array}$} & $\begin{array}{l}\text { Strongly } \\
\text { disagree/ } \\
\text { Disagree }\end{array}$ & 85 & 5.8 & $31.8(27)$ & 29.08 & $<0.001^{*}$ & $29.7(11)$ & 0.89 & 0.640 \\
\hline & Neutral & 156 & 10.6 & $35.3(55)$ & & & $9.5(71)$ & & \\
\hline & $\begin{array}{l}\text { Strongly agree } \\
\text { /Agree }\end{array}$ & 1228 & 83.6 & $\begin{array}{l}52.9 \\
(650)\end{array}$ & & & $\begin{array}{l}29.2 \\
(186)\end{array}$ & & \\
\hline \multirow[t]{3}{*}{$\begin{array}{l}\text { I believe the public fear is } \\
\text { dysfunctional }\end{array}$} & $\begin{array}{l}\text { Strongly } \\
\text { disagree/ } \\
\text { Disagree }\end{array}$ & 759 & 51.7 & $\begin{array}{l}51.5 \\
(391)\end{array}$ & 10.86 & $0.004^{*}$ & $\begin{array}{l}28.5 \\
(107)\end{array}$ & 0.357 & 0.836 \\
\hline & Neutral & 261 & 17.8 & $\begin{array}{l}40.6 \\
(106)\end{array}$ & & & $13.9(29)$ & & \\
\hline & $\begin{array}{l}\text { Strongly agree/ } \\
\text { Agree }\end{array}$ & 448 & 30.6 & $\begin{array}{l}52.3 \\
(235)\end{array}$ & & & $30(74)$ & & \\
\hline \multirow[t]{3}{*}{$\begin{array}{l}\text { I am worried about catching } \\
\text { COVID-19 }\end{array}$} & $\begin{array}{l}\text { Not worried at } \\
\text { all }\end{array}$ & 138 & 9.5 & $21.7(30)$ & 176.98 & $<0.001^{*}$ & $6.6(7)$ & 55.25 & $\leq 0.001^{*}$ \\
\hline & $\begin{array}{l}\text { Little/ } \\
\text { Somewhat } \\
\text { worried }\end{array}$ & 801 & 55.2 & $\begin{array}{l}40.6 \\
(325)\end{array}$ & & & $10.3(67)$ & & \\
\hline & $\begin{array}{l}\text { Very/Extremely } \\
\text { worried }\end{array}$ & 511 & 35.2 & $\begin{array}{l}72.6 \\
(371)\end{array}$ & & & $\begin{array}{l}26.3 \\
(104)\end{array}$ & & \\
\hline \multirow[t]{3}{*}{$\begin{array}{l}\text { I am worried about my parents } \\
\text { catch COVID-19 }\end{array}$} & $\begin{array}{l}\text { Not worried at } \\
\text { all }\end{array}$ & 49 & 3.6 & $14.3(7)$ & 98.86 & $\leq 0.001^{*}$ & $5.1(2)$ & 18.24 & $\leq 0.001^{*}$ \\
\hline & $\begin{array}{l}\text { Little/ } \\
\text { Somewhat } \\
\text { worried }\end{array}$ & 294 & 21.4 & $29.6(87)$ & & & $8.2(20)$ & & \\
\hline & $\begin{array}{l}\text { Very/Extremely } \\
\text { worried }\end{array}$ & 1028 & 75.0 & $57.8(594)$ & & & $\begin{array}{l}18.4 \\
(146)\end{array}$ & & \\
\hline \multirow[t]{3}{*}{$\begin{array}{l}\text { I am worried my children catch } \\
\text { COVID-19 }\end{array}$} & $\begin{array}{l}\text { Not worried at } \\
\text { all }\end{array}$ & 62 & 5.3 & $19.4(12)$ & 110.44 & $\leq 0.001^{*}$ & $4(2)$ & 23.14 & $\leq 0.001^{*}$ \\
\hline & $\begin{array}{l}\text { Little/ } \\
\text { Somewhat } \\
\text { worried }\end{array}$ & 342 & 29.2 & 29.8(102) & & & $10(32)$ & & \\
\hline & $\begin{array}{l}\text { Very/Extremely } \\
\text { worried }\end{array}$ & 766 & 65.5 & $60.2(461)$ & & & $\begin{array}{l}20.4 \\
(141)\end{array}$ & & \\
\hline \multirow[t]{3}{*}{$\begin{array}{l}\text { I am worried about what COVID-19 } \\
\text { can do to me health wise }\end{array}$} & $\begin{array}{l}\text { Not worried at } \\
\text { all }\end{array}$ & 121 & 8.4 & $17.4(21)$ & 178.81 & $\leq 0.001^{*}$ & $3.1(3)$ & 44.22 & $\leq 0.001^{*}$ \\
\hline & $\begin{array}{l}\text { Little/ } \\
\text { Somewhat } \\
\text { worried }\end{array}$ & 667 & 46.4 & $\begin{array}{l}38.4 \\
(256)\end{array}$ & & & $10.5(56)$ & & \\
\hline & $\begin{array}{l}\text { Very/Extremely } \\
\text { worried }\end{array}$ & 647 & 45.1 & $\begin{array}{l}68.8 \\
(445)\end{array}$ & & & $\begin{array}{l}23.1 \\
(117)\end{array}$ & & \\
\hline \multirow[t]{3}{*}{ I am worried about social isolation } & $\begin{array}{l}\text { Not worried at } \\
\text { all }\end{array}$ & 375 & 26.1 & $34.4(129)$ & 81.71 & $\leq 0.001^{*}$ & $9.2(27)$ & 58.29 & $\leq 0.001^{*}$ \\
\hline & $\begin{array}{l}\text { Little/ } \\
\text { Somewhat } \\
\text { worried }\end{array}$ & 608 & 42.3 & $48.2(293)$ & & & $10.6(52)$ & & \\
\hline & $\begin{array}{l}\text { Very/Extremely } \\
\text { worried }\end{array}$ & 454 & 31.6 & $65.6(298)$ & & & $27.7(99)$ & & \\
\hline \multirow[t]{2}{*}{$\begin{array}{l}\text { I am worried about loss of income } \\
\text { if infected with COVID-19 }\end{array}$} & $\begin{array}{l}\text { Not worried at } \\
\text { all }\end{array}$ & 265 & 18.8 & $32.1(85)$ & 73.63 & $\leq 0.001^{*}$ & $7.9(16)$ & 22.91 & $\leq 0.001^{*}$ \\
\hline & $\begin{array}{l}\text { Little/ } \\
\text { Somewhat } \\
\text { worried }\end{array}$ & 441 & 32.9 & $\begin{array}{l}44.4 \\
(196)\end{array}$ & & & $12.1(44)$ & & \\
\hline
\end{tabular}


Table 5 Worry about COVID-19 by GAD-7 score $\geq 8$ and reported Child SDQ score $\geq 5$ ( $N=1469)$ (Continued)

\begin{tabular}{|c|c|c|c|c|c|c|c|c|c|}
\hline \multirow[b]{2}{*}{ Characteristics } & \multirow[b]{2}{*}{ Category } & \multirow[b]{2}{*}{ Frequency $(\mathrm{n})$} & \multirow[b]{2}{*}{$\%$} & \multicolumn{3}{|c|}{ Anxiety GAD-7 Score $(\geq 8)$} & \multicolumn{3}{|c|}{$\begin{array}{l}\text { Reported Children Emotional } \\
\text { SDQ Score (SDQ } \geq 5)\end{array}$} \\
\hline & & & & $\%(n)$ & Chi-Square $x^{2}$ & p-value & $\%(n)$ & Chi-square $x^{2}$ & $p$-value \\
\hline & $\begin{array}{l}\text { Very/Extremely } \\
\text { worried }\end{array}$ & 633 & 47.3 & $\begin{array}{l}61.6 \\
(390)\end{array}$ & & & $20.7(107)$ & & \\
\hline \multirow[t]{3}{*}{$\begin{array}{l}\text { I am worried I transmit COVID-19 } \\
\text { to others }\end{array}$} & $\begin{array}{l}\text { Not worried at } \\
\text { all }\end{array}$ & 104 & 8.5 & $31.7(33)$ & 79.81 & $\leq 0.001^{*}$ & $8.5(8)$ & 32.48 & $\leq 0.001^{*}$ \\
\hline & $\begin{array}{l}\text { Little/ } \\
\text { Somewhat } \\
\text { worried }\end{array}$ & 328 & 27.0 & $\begin{array}{l}34.5 \\
(113)\end{array}$ & & & $7.4(20)$ & & \\
\hline & $\begin{array}{l}\text { Very/Extremely } \\
\text { worried }\end{array}$ & 785 & 64.5 & $\begin{array}{l}60.5 \\
(475)\end{array}$ & & & $\begin{array}{l}21.6 \\
(131)\end{array}$ & & \\
\hline \multirow[t]{2}{*}{ Overall worry about COVID-19 } & $\begin{array}{l}\text { Low levels of } \\
\text { worry }\end{array}$ & 394 & 26.8 & $\begin{array}{l}27.4 \\
(108)\end{array}$ & 148.7 & $\leq 0.001^{*}$ & $6.4(18)$ & 44.9 & $\leq 0.001^{*}$ \\
\hline & $\begin{array}{l}\text { High levels of } \\
\text { worry }\end{array}$ & 1075 & 73.2 & $58(624)$ & & & $\begin{array}{l}18.2 \\
(160)\end{array}$ & & \\
\hline
\end{tabular}

"Significant at $p<0.05$

scores were included in the SDQ score, a quarter of children in our study showed parent reported emotional problems. Higher levels of anxiety and emotional problems were found among school age and adolescent age groups which is consistent with earlier reports from Germany, China, Italy, Spain and Ireland [61-64]. COVID-19 adversely affects the mental health of children, particularly those in lower grades. Social isolation, prolonged school closure, challenges with online learning and uncertainty over assessments and examinations all cause mental stress, especially among adolescents [64]. Although we did not interview children directly, we used parent/teacher questionnaires, which were validated against structured diagnostic interviews. Parents and teachers, and especially parents who are teachers, were the best informants of emotional problems in children. Parents who regularly utilized coping strategies with their children reported higher SDQ scores than those who did not. This highlights the need for educating parents about effective coping strategies and mechanisms particularly for nurturing and implementing resilience in children which will assist in overcoming distress and psychological consequences. Further research should measure the effectiveness of these strategies in addressing anxiety disorders in children. We found that higher parental anxiety was a significant predictor of children's SDQ score, suggesting that parental anxiety might be a unique factor in explaining anxiety disorders in children. This is consistent with research where mental health service utilization among adolescents was associated with parental anxiety and depression [23]. Furthermore, it is uncertain whether these findings demonstrate the likelihood that anxious parents are more likely to report or recognize anxiety problems in their children, or whether children of parents with anxiety disorders have an increased risk of also being anxious [65]. This should be included in future research on the psychological impact of public health emergencies in this population. Further prospective research will be useful in identifying the determinants and characteristics associated with the onset, course and outcome of anxiety and emotional disorders among adults and children.

\section{Limitations}

The use of convenience sampling and its descriptive nature through an online survey may not allow the generalization of results. However, considering the need for a quick method to assess the psychological impact on a population during a rapidly evolving infectious disease outbreak, the online survey proved best [66]. Responses were collected from all over the UAE in addition to countries outside the UAE (due to online and social media use) with a good response rate allowing for some degree of representativeness. The self-reported data in the survey may lead to response biases specifically for reported behavioral changes, coping strategies and measures taken where participants provide socially desirable results. Selfreported levels of anxiety among adults and emotional disorders in children may not be as accurate as those assessed by healthcare professionals. Furthermore, since no single informant can be considered the gold standard of child psychopathology, interviewing children regarding their own symptoms is necessary and several instruments offer developmentally sensitive screening methods to obtain unique information from young children about their mental health problems. These can include pictorial or multimedia self-report screening for mental disorders including anxiety and 
Table 6 Coping strategies used with children during COVID-19 by GAD-7 score and SDQ score ( $\mathrm{N}=1469)$

\begin{tabular}{|c|c|c|c|c|c|c|c|c|c|}
\hline \multirow[b]{2}{*}{ Characteristics } & \multirow[b]{2}{*}{ Category } & \multirow[b]{2}{*}{$\begin{array}{l}\text { Frequency } \\
\text { (n) }\end{array}$} & \multirow[b]{2}{*}{$\%$} & \multicolumn{3}{|c|}{ Anxiety GAD-7 Score $(\geq 8)$} & \multicolumn{3}{|c|}{ SDQ Score (SDQ $\geq 5$ ) } \\
\hline & & & & $\%(\mathrm{n})$ & $\begin{array}{l}\text { Chi-square } \\
x^{2}\end{array}$ & $\begin{array}{l}p- \\
\text { value }\end{array}$ & $\%(n)$ & $\begin{array}{l}\text { Chi-square } \\
x^{2}\end{array}$ & $\begin{array}{l}p- \\
\text { value }\end{array}$ \\
\hline \multirow{4}{*}{$\begin{array}{l}\text { I have openly discussed COVID-19 with } \\
\text { my family }\end{array}$} & No children & 178 & 12.1 & $53.9(96)$ & 10.79 & $0.013^{*}$ & $2.7(2)$ & 13.42 & $0.004^{*}$ \\
\hline & Never & 27 & 1.8 & $33.3(9)$ & & & $4.2(1)$ & & \\
\hline & Occasionally & 259 & 17.6 & $\begin{array}{l}42.5 \\
(110)\end{array}$ & & & $\begin{array}{l}14.1 \\
(30)\end{array}$ & & \\
\hline & $\begin{array}{l}\text { Most of the time/ } \\
\text { Always }\end{array}$ & 1005 & 68.4 & $\begin{array}{l}51.4 \\
(517)\end{array}$ & & & $\begin{array}{l}17.1 \\
(145)\end{array}$ & & \\
\hline \multirow[t]{4}{*}{ I have educated my children about PPE } & No children & 316 & 21.5 & $\begin{array}{l}52.2 \\
(165)\end{array}$ & 10.19 & $0.017^{*}$ & $2.4(3)$ & 21.27 & $\leq 0.001^{*}$ \\
\hline & Never & 13 & 0.9 & $23.1(3)$ & & & $0(0)$ & & \\
\hline & Occasionally & 56 & 3.8 & $33.9(19)$ & & & $10.9(5)$ & & \\
\hline & $\begin{array}{l}\text { Most of the time/ } \\
\text { Always }\end{array}$ & 1084 & 73.8 & $\begin{array}{l}50.3 \\
(545)\end{array}$ & & & $\begin{array}{l}17.3 \\
(170)\end{array}$ & & \\
\hline \multirow[t]{4}{*}{ I reassure my children they are safe } & No children & 331 & 22.5 & $\begin{array}{l}52.6 \\
(174)\end{array}$ & 1.89 & 0.595 & $2.3(3)$ & 23.80 & $\leq 0.001^{*}$ \\
\hline & Never & 20 & 1.4 & $45(9)$ & & & $0(0)$ & & \\
\hline & Occasionally & 92 & 6.3 & $45.7(42)$ & & & $\begin{array}{l}20.3 \\
(16)\end{array}$ & & \\
\hline & $\begin{array}{l}\text { Most of the time/ } \\
\text { Always }\end{array}$ & 1026 & 69.8 & $\begin{array}{l}49.4 \\
(507)\end{array}$ & & & $\begin{array}{l}17 \\
(159)\end{array}$ & & \\
\hline \multirow[t]{4}{*}{ I have limited news exposure } & No children & 407 & 27.7 & $\begin{array}{l}50.9 \\
(207)\end{array}$ & 11.20 & $0.011^{*}$ & $3(6)$ & 37.10 & $\leq 0.001^{*}$ \\
\hline & Never & 205 & 14.0 & $41(84)$ & & & $\begin{array}{l}11.2 \\
(21)\end{array}$ & & \\
\hline & Occasionally & 216 & 14.7 & $45.8(99)$ & & & $\begin{array}{l}22.1 \\
(43)\end{array}$ & & \\
\hline & $\begin{array}{l}\text { Most of the time/ } \\
\text { Always }\end{array}$ & 641 & 43.6 & $\begin{array}{l}53.4 \\
(342)\end{array}$ & & & $\begin{array}{l}18.6 \\
(108)\end{array}$ & & \\
\hline \multirow[t]{4}{*}{ I have created a schedule for learning } & No children & 335 & 22.8 & $\begin{array}{l}48.4 \\
(162)\end{array}$ & 0.51 & 0.916 & $6.6(10)$ & 10.40 & $0.015^{*}$ \\
\hline & Never & 104 & 7.1 & $51(53)$ & & & $\begin{array}{l}17.4 \\
(16)\end{array}$ & & \\
\hline & Occasionally & 288 & 19.6 & $51(147)$ & & & $\begin{array}{l}16.4 \\
(42)\end{array}$ & & \\
\hline & $\begin{array}{l}\text { Most of the time/ } \\
\text { Always }\end{array}$ & 742 & 50.5 & $\begin{array}{l}49.9 \\
(370)\end{array}$ & & & $\begin{array}{l}16.7 \\
(111)\end{array}$ & & \\
\hline \multirow[t]{4}{*}{ I have maintained a regular routine } & No children & 225 & 15.3 & $\begin{array}{l}50.7 \\
(114)\end{array}$ & 2.26 & 0.521 & $4.4(4)$ & 8.99 & $0.029^{*}$ \\
\hline & Never & 47 & 3.2 & $46.8(22)$ & & & $14.7(5)$ & & \\
\hline & Occasionally & 185 & 12.6 & $\begin{array}{l}54.6 \\
(101)\end{array}$ & & & $\begin{array}{l}16.2 \\
(25)\end{array}$ & & \\
\hline & $\begin{array}{l}\text { Most of the time/ } \\
\text { Always }\end{array}$ & 1012 & 68.9 & $\begin{array}{l}48.9 \\
(495)\end{array}$ & & & $\begin{array}{l}16.3 \\
(144)\end{array}$ & & \\
\hline \multirow[t]{2}{*}{$\begin{array}{l}\text { Overall Coping strategies Total } \\
\text { Category }\end{array}$} & $\begin{array}{l}\text { Low use of coping } \\
\text { strategies }\end{array}$ & 705 & 48.0 & 49.7(366) & 1.65 & 0.199 & $5.6(10)$ & 9.01 & $\begin{array}{l}< \\
0.001^{*}\end{array}$ \\
\hline & $\begin{array}{l}\text { High use of coping } \\
\text { strategies }\end{array}$ & 765 & 52.0 & $50.3(371)$ & & & $\begin{array}{l}17.1 \\
(168)\end{array}$ & & \\
\hline
\end{tabular}


Table 7 Predictors for anxiety (GAD-7 score $\geq 8$ ) in adult population and predictors for parent/teacher reported emotional problems in children (SDQ score $\geq 5$ ) using multivariable logistic regression analysis

\begin{tabular}{|c|c|c|c|c|c|}
\hline Variable & & $b$ & $S E(b)$ & P-value & aOR $[95 \% \mathrm{Cl}]$ \\
\hline \multicolumn{6}{|c|}{ Generalized Anxiety Disorder (GAD-7) score $(n=1469) \#$} \\
\hline \multirow[t]{2}{*}{ Sex } & Female & 0.649 & 0.178 & $<0.001$ & $1.91[1.35-2.71]$ \\
\hline & Male $e^{a}$ & - & - & - & 1 \\
\hline \multirow[t]{2}{*}{ Precautionary Measures } & Agree & -0.740 & 0.146 & $<0.001$ & $0.48[0.36-0.63]$ \\
\hline & Disagree $^{a}$ & - & - & - & 1 \\
\hline \multirow[t]{2}{*}{ Public fear Justifiable } & Agree & 1.811 & 1.082 & 0.094 & $6.11[0.73-51.0]$ \\
\hline & Disagree $^{a}$ & - & - & - & 1 \\
\hline \multirow[t]{2}{*}{ Levels of Worry associated with COVID-19 } & High & 1.336 & 0.139 & $<0.001$ & $3.80[2.90-5.00]$ \\
\hline & Low $^{a}$ & - & - & - & 1 \\
\hline \multirow[t]{2}{*}{ Will take COVID-19 Vaccine } & Yes & 0.446 & 0.1478 & 0.003 & 1.57 [1.17-2.09] \\
\hline & $\mathrm{No}^{\mathrm{a}}$ & - & - & - & 1 \\
\hline \multirow[t]{2}{*}{ Symptoms- Sore throat } & Yes & 0.447 & 0.173 & 0.010 & $1.56[1.17-2.09]$ \\
\hline & $\mathrm{No}^{\mathrm{a}}$ & - & - & - & 1 \\
\hline \multirow[t]{2}{*}{ Taking Vitamin C } & Yes & 0.344 & 0.134 & 0.010 & 1.41 [1.09-1.83] \\
\hline & $\mathrm{No}^{\mathrm{a}}$ & - & - & - & 1 \\
\hline \multirow[t]{2}{*}{ Smoker } & Yes & 0.435 & 0.194 & 0.025 & $1.55[1.06-2.26]$ \\
\hline & $\mathrm{No}^{\mathrm{a}}$ & - & - & - & 1 \\
\hline
\end{tabular}

Model fit: Hosmer and Lemeshow test $X^{2}(8, N=1469)=7.16, p=0.519-2$ log likelihood 1081.692

Strengths and Difficulties Questionnaire (SDQ) score $(n=1160)^{*}$

\begin{tabular}{|c|c|c|c|c|c|}
\hline \multirow[t]{3}{*}{ Adult relationship to child/ren } & Parent only & 0.854 & 0.493 & 0.884 & $2.35[0.89-6.17]$ \\
\hline & Parent \& Teacher & 1.626 & 0.519 & $<0.001$ & 5.08 [1.84-14.0] \\
\hline & Teacher only ${ }^{\mathrm{a}}$ & - & - & - & 1 \\
\hline \multirow[t]{2}{*}{ Child/ren in lower secondary education } & Yes & 0.522 & 0.189 & 0.006 & $1.69[1.16-2.44]$ \\
\hline & $\mathrm{No}^{\mathrm{a}}$ & - & - & - & 1 \\
\hline \multirow[t]{2}{*}{ Child/ren in higher secondary education } & Yes & 0.460 & 0.199 & 0.021 & $1.59[1.07-2.34]$ \\
\hline & $\mathrm{No}^{\mathrm{a}}$ & - & - & - & 1 \\
\hline \multirow[t]{4}{*}{ Anxiety level (GAD-7) } & Severe & 1.94 & 0.355 & $<0.001$ & $7.00[3.45-14.0]$ \\
\hline & Moderate & 1.505 & 0.340 & 0.013 & $4.51[2.31-8.80]$ \\
\hline & Mild & 0.582 & 0.344 & 0.011 & 1.79 [0.91-3.50] \\
\hline & Minimal $^{\mathrm{a}}$ & - & - & - & 1 \\
\hline \multirow[t]{4}{*}{ Difficulty of parent/teacher to get things done } & Extremely & 1.299 & 0.439 & 0.003 & $3.70[1.55-8.66]$ \\
\hline & Very & 1.403 & 0.348 & $<0.001$ & $4.07[2.10-8.05]$ \\
\hline & Somewhat & 0.805 & 0.306 & 0.009 & $2.24[1.23-4.08]$ \\
\hline & Not difficult at all ${ }^{\mathrm{a}}$ & - & - & - & 1 \\
\hline
\end{tabular}

Model fit: Hosmer and Lemeshow test $\left.X^{2}(7, N=1160)=11.99, p=0.101\right) ;-2$ log likelihood 764.550

${ }^{a}$ reference group, $b$ parameter estimate, SE Std Error, $a O R$ Adjusted Odds Ratio, $C$ C Confidence Interval. "Logistic regression adjusted for the effects of sex, age, age of children, perception of fear, perception of likelihood to contract COVID-19 and to develop severe disease, headaches, sore throat, asthma, measures taken for symptoms, smoking, and changed smoking habits, likelihood of vaccination for self and children, hygienic behavior and attitudes towards precautionary measures

*Logistic regression adjusted for adult's relationship to child, age (school-aged or adolescent), marital status, educational level of child (lower secondary and higher secondary), coping strategies, worry, parental anxiety levels (GAD-7) and difficulty getting things done 
emotional problems. However, considering the current pandemic, lockdowns, restricted movement and access to participants, this was not possible. Nonetheless, future research should potentially take this into consideration.

\section{Conclusion}

This is the first study to provide information on the psychological impact of COVID-19 on parents and children in the UAE, with association found between parental and child anxiety. Worry and fear are significant predictors of growing anxiety in the UAE. Policymakers should use the findings from this study to develop effective screening methods and interventions to improve mental health, especially for children. These can include more accessible and innovative approaches to mental health programs such as tele-mental health consultations, production and dissemination of creative audio-visual and engaging material related to COVID-19, online schooling, healthy parenting, mental health awareness and coping mechanisms. Such strategies can reduce the psychological impact of COVID-19 in the UAE and other public health emergencies in the future.

\section{Abbreviations}

COVID-19: Coronavirus Disease 2019; UAE: United Arab Emirates; GAD: Generalized Anxiety Disorder; GAD-7 Scale: Generalized Anxiety Disorder 7 Scale; SDQ: Strengths and Difficulties Questionnaire; WHO: World Health Organization; SARS: Severe Acute Respiratory Syndrome; UK: United Kingdom; IP: Internet Protocol

\section{Supplementary Information}

The online version contains supplementary material available at https://doi. org/10.1186/s12888-021-03213-2.

Additional file 1.

\section{Acknowledgements}

The authors would like to thank all the individuals who generously shared their time and took part in the study.

\section{Authors' contributions}

$B S, R H, F S$, and $M T$ conceived, designed and initiated the study. AA, IE, AH, ES contributed to the planning and implementation of the study. AAS analyzed survey data. BS, AAS interpreted the results. BS drafted the manuscript with input from $R H, I E, A A, F S, A H, M T, E S$ and $Q H$. All authors read and approved the final version of the manuscript.

\section{Funding}

This research has been financially supported by a Clinical Epidemiology Research group operational grant (Grant code: 150389); COVID-19 research grant (CoV19-0301) to BS, University of Sharjah, UAE; COVID-19 research grant (CoV19-0307), and collaborative research grant (Grant code: 2001090278) to RH, University of Sharjah, UAE; and by Prince Abdullah Ben Khalid Celiac Disease Research Chair, under the Vice Deanship of Research Chairs, King Saud University, Riyadh, Kingdom of Saudi Arabia. The funding bodies had no further role in the study design, the collection, analysis, and interpretation of data, the writing of the manuscript and the decision to submit the paper for publication.

\section{Availability of data and materials}

The datasets used and/or analysed during the current study are available from the corresponding author on reasonable request.

\section{Declarations}

Ethics approval and consent to participate

All procedures performed in the study were in accordance with the ethical standards of the institutional and/or national research committee and with the 1964 Helsinki declaration and its later amendments or comparable ethical standards. This study protocol was evaluated and approved by the University of Sharjah and the United Arab Emirates University ethical review boards. Written consent was obtained prior to individual participation.

\section{Consent for publication}

Not applicable.

\section{Competing interests}

The authors declare that they have no competing interests.

\section{Author details}

'Department of Family and Community Medicine and Behavioral Sciences, College of Medicine, University of Sharjah, Sharjah, United Arab Emirates.

${ }^{2}$ Sharjah Institute of Medical Research, University of Sharjah, Sharjah, United Arab Emirates. ${ }^{3}$ Child and Adolescent Mental Health Center of Excellence, Al Jalila Children's Specialty Hospital, Dubai, United Arab Emirates. ${ }^{4}$ Mohamed Bin Rashid University of Medicine and Health Sciences, Dubai, United Arab Emirates. ${ }^{5}$ Institute of Public Health, College of Medicine and Health Sciences, United Arab Emirates University, Al Ain, Abu Dhabi, United Arab Emirates. ${ }^{6}$ Department of Pediatrics, College of Medicine, King Saud University, Riyadh, Kingdom of Saudi Arabia. ${ }^{7}$ Prince Abdullah Ben Khaled Celiac Disease Research Chair, Department of Pediatrics, Faculty of Medicine, King Saud University, Riyadh, Kingdom of Saudi Arabia. ${ }^{8}$ Department of Psychiatry and Behavioral Sciences, College of Medicine and Health Sciences, United Arab Emirates University, Al Ain, United Arab Emirates. ${ }^{9}$ Department of Clinical Sciences, College of Medicine, University of Sharjah, Sharjah, United Arab Emirates.

Received: 25 August 2020 Accepted: 13 April 2021

Published online: 03 May 2021

\section{References}

1. WHO. Coronavirus disease (COVID-19) outbreak 2020. Available from: http:// www.covid19.who.int/. Accessed 12 June 2020.

2. WHO. Director General's opening remarks at the media briefing on COVID19, 11th March 20202020 [updated 30-3-2020. Available from: http://www. who.int/dg/speeches/detail/who-director-general-s-opening-remarks-at-themedia-briefing-on-covid-19\%2D\%2D-11-march-2020. Accessed 12 June 2020

3. Worldometers.info. COVID-19 CORONAVIRUS PANDEMIC. Dover, Delaware, U.S.A. 2020. Available from: http://www.worldometers.info/coronavirus/. Accessed 7 Mar 2021

4. Wang C, Pan R, Wan X, Tan Y, Xu L, Mclntyre RS, et al. A longitudinal study on the mental health of general population during the COVID-19 epidemic in China. Brain Behav Immunity. 2020;87:40-8.

5. Rubin GJ, Wessely $\mathrm{S}$. The psychological effects of quarantining a city. $\mathrm{Br}$ Med J. 2020;368:m313.

6. Sim K, Huak Chan Y, Chong PN, Chua HC, Wen SS. Psychosocial and coping responses within the community health care setting towards a national outbreak of an infectious disease. J Psychosom Res. 2010;68(2):195-202. https://doi.org/10.1016/j.jpsychores.2009.04.004.

7. Balkhy HH, Abolfotouh MA, Al-Hathlool RH, Al-Jumah MA. Awareness, attitudes, and practices related to the swine influenza pandemic among the Saudi public. BMC Infect Dis. 2010;10(1):42. https://doi.org/10.1186/14 71-2334-10-42.

8. Lau JT, Yang X, Tsui HY, Pang E. SARS related preventive and risk behaviours practised by Hong Kong-mainland China cross border travellers during the outbreak of the SARS epidemic in Hong Kong. J Epidemiol Community Health. 2004;58(12):988-96. https://doi.org/10.1136/jech.2003.017483.

9. Leung GM, Lam TH, Ho LM, Ho SY, Chan BH, Wong IO, et al. The impact of community psychological responses on outbreak control for severe acute 
respiratory syndrome in Hong Kong. J Epidemiol Community Health. 2003; 57(11):857-63. https://doi.org/10.1136/jech.57.11.857.

10. Huang $Y$, Zhao N. Generalized anxiety disorder, depressive symptoms and sleep quality during COVID-19 outbreak in China: a web-based crosssectional survey. Psychiatry Res. 2020;288:112954. https://doi.org/10.1016/j. psychres.2020.112954.

11. Wang C, Pan R, Wan X, Tan Y, Xu L, Ho CS, et al. Immediate Psychological Responses and Associated Factors during the Initial Stage of the 2019

Coronavirus Disease (COVID-19) Epidemic among the General Population in China. Int J Environ Res Public Health. 2020;17(5):1729.

12. Rodríguez-Rey R, Garrido-Hernansaiz H, Collado S. Psychological Impact and Associated Factors During the Initial Stage of the Coronavirus (COVID-19) Pandemic Among the General Population in Spain. Front Psychol. 2020;11: 1540 .

13. Shevlin M, McBride O, Murphy J, Miller JG, Hartman TK, Levita L, et al. Anxiety, depression, traumatic stress and COVID-19-related anxiety in the UK general population during the COVID-19 pandemic. BJPsych Open. 2020; 6(6):e125. https://doi.org/10.1192/bjo.2020.109.

14. Verma S, Mishra A. Depression, anxiety, and stress and socio-demographic correlates among general Indian public during COVID-19. Int J Soc Psychiatry. 2020;66(8):756-62. https://doi.org/10.1177/0020764020934508.

15. Lakhan R, Agrawal A, Sharma M. Prevalence of depression, anxiety, and stress during COVID-19 pandemic. J Neurosci Rural Pract. 2020;11(4):519-25. https://doi.org/10.1055/s-0040-1716442.

16. de Girolamo G, Cerveri G, Clerici M, Monzani E, Spinogatti F, Starace F, et al. Mental Health in the Coronavirus Disease 2019 Emergency-the Italian response. JAMA Psychiatry 2020;77(9):974-6.

17. Thomas J, Barbato M, Verlinden M, Gaspar C, Moussa M, Ghorayeb J, et al. Psychosocial correlates of depression and anxiety in the United Arab Emirates during the COVID-19 pandemic. Front Psychiatry. 2020;11:564172. https://doi.org/10.3389/fpsyt.2020.564172.

18. Shekerdemian LS, Mahmood NR, Wolfe KK, Riggs BJ, Ross CE, McKiernan CA, et al. Characteristics and outcomes of children with coronavirus disease 2019 (COVID-19) infection admitted to US and Canadian pediatric intensive care units. JAMA Pediatr. 2020;174(9):868-73. https://doi.org/10.1001/jama pediatrics.2020.1948.

19. Stark AM, White AE, Rotter NS, Basu A. Shifting from survival to supporting resilience in children and families in the COVID-19 pandemic: lessons for informing U.S. mental health priorities. Psychol Trauma Theory Res Pract Policy. 2020;12(S1):S133-S5. https://doi.org/10.1037/tra0000781.

20. Golberstein E, Wen H, Miller BF. Coronavirus disease 2019 (COVID-19) and mental health for children and adolescents. JAMA Pediatr. 2020;174(9):81920. https://doi.org/10.1001/jamapediatrics.2020.1456.

21. Al-Yateem N, Bani Issa W, Rossiter RC, Al-Shujairi A, Radwan H, Awad M, et al. Anxiety related disorders in adolescents in the United Arab Emirates: a population based cross-sectional study. BMC Pediatr. 2020;20(1):245. https:// doi.org/10.1186/s12887-020-02155-0.

22. Cobham VE, McDermott B, Haslam D, Sanders MR. The role of parents, parenting and the family environment in Children's post-disaster mental health. Curr Psychiatry Rep. 2016;18(6):53. https://doi.org/10.1007/s11920-016-0691-4.

23. Essau CA. Frequency and patterns of mental health services utilization among adolescents with anxiety and depressive disorders. Depress Anxiety. 2005:22(3):130-7. https://doi.org/10.1002/da.20115.

24. Jongerden $L$, Simon E, Bodden DH, Dirksen CD, Bogels SM. Factors associated with the referral of anxious children to mental health care: the influence of family functioning, parenting, parental anxiety and child impairment. Int J Methods Psychiatr Res. 2015;24(1):46-57. https://doi.org/1 0.1002/mpr.1457.

25. Burstein M, Ginsburg GS, Tein J-Y. Parental anxiety and child symptomatology: an examination of additive and interactive effects of parent psychopathology. [corrected]. J Abnorm Child Psychol. 2010;38(7): 897-909. https://doi.org/10.1007/s10802-010-9415-0.

26. Cohodes EM, McCauley S, Gee DG. Parental buffering of stress in the time of COVID-19: family-level factors may moderate the association between pandemic-related stress and youth symptomatology. Res Child Adolesc Psychopathol. 2021;16:1-14.

27. Cusinato M, lannattone S, Spoto A, Poli M, Moretti C, Gatta M, et al. Stress, Resilience, and Well-Being in Italian Children and Their Parents during the COVID-19 Pandemic. Int J Environ Res Public Health. 2020;17(22):8297.

28. Boman F, Stafström M, Lundin N, Moghadassi M, Törnhage CJ, Östergren PO. Comparing parent and teacher assessments of mental health in elementary school children. Scand J Public Health. 2016;44(2):168-76. https://doi.org/10.1177/1403494815610929.

29. Goodman R, Ford T, Simmons H, Gatward R, Meltzer H. Using the strengths and difficulties questionnaire (SDQ) to screen for child psychiatric disorders in a community sample. Int Rev Psychiatry. 2003;15(1-2):166-72. https://doi. org/10.1080/0954026021000046128.

30. Aelterman A, Engels N, Van Petegem K, Pierre VJ. The well-being of teachers in Flanders: the importance of a supportive school culture. Educ Stud. 2007; 33(3):285-97. https://doi.org/10.1080/03055690701423085.

31. Telles S, Gupta RK, Bhardwaj AK, Singh N, Mishra P, Pal DK, et al. Increased mental well-being and reduced state anxiety in teachers after participation in a residential yoga program. Med Sci Monit Basic Res. 2018;24:105-12. https://doi.org/10.12659/MSMBR.909200.

32. EdArabia. Schools in the UAE. 2020. Available from: http://www.edarabia. $\mathrm{com} / \mathrm{schools} /$ uae. Accessed 11 Mar 2020.

33. SurveyMonkey. San Mateo. Available from: http://www.surveymonkey.com. Accessed 13 Mar 2020

34. Al-Rabiaah A, Temsah MH, Al-Eyadhy AA, Hasan GM, Al-Zamil F, Al-Subaie S, et al. Middle East respiratory syndrome-Corona virus (MERS-CoV) associated stress among medical students at a university teaching hospital in Saudi Arabia. J Infect Public Health. 2020;13(5):687-91. https://doi.org/10.1016/j. jiph.2020.01.005.

35. Bults M, Beaujean DJ, Richardus JH, Voeten HA. Perceptions and behavioral responses of the general public during the 2009 influenza a (H1N1) pandemic: a systematic review. Disaster Med Public Health Preparedness. 2015;9(2):207-19. https://doi.org/10.1017/dmp.2014.160.

36. DeCoster J, Gallucci M, Iselin A-MR. Best practices for using median splits, artificial categorization, and their continuous alternatives. J Experiment Psychopathol. 2011;2(2):197-209. https://doi.org/10.5127/jep.008310.

37. Leung GM, Ho LM, Chan SK, Ho SY, Bacon-Shone J, Choy RY, et al. Longitudinal assessment of community psychobehavioral responses during and after the 2003 outbreak of severe acute respiratory syndrome in Hong Kong. Clin Infect Dis. 2005;40(12):1713-20. https://doi.org/10.1086/429923.

38. Spitzer RL, Kroenke K, Williams JB, Lowe B. A brief measure for assessing generalized anxiety disorder: the GAD-7. Arch Intern Med. 2006;166(10): 1092-7. https://doi.org/10.1001/archinte.166.10.1092.

39. Kroenke K, Spitzer RL, Williams JB, Monahan PO, Lowe B. Anxiety disorders in primary care: prevalence, impairment, comorbidity, and detection. Ann Intern Med. 2007;146(5):317-25. https://doi.org/10.7326/0003-4819-146-5-2 00703060-00004.

40. Goodman R. The strengths and difficulties questionnaire: a research note. J Child Psychol Psychiatry. 1997;38(5):581-6. https://doi.org/10.1111/j.1469-761 0.1997.tb01545.x.

41. Goodman A, Goodman R. Strengths and difficulties questionnaire as a dimensional measure of child mental health. J Am Acad Child Adolesc Psychiatry. 2009;48(4):400-3. https://doi.org/10.1097/CHI.0b013e3181985068.

42. Silva TBF, Osório FL, Loureiro SR. SDQ: discriminative validity and diagnostic potential. Front Pyschol. 2015;6:811

43. Goodman A. Scoring the Strengths \& Difficulties Questionnaire for age 4-17. Available from: http://www.ehcap.co.uk/content/sites/ehcap/uploads/ NewsDocuments/236/SDQEnglishUK4-17scoring-1.PDF. Accessed 17 May 2020

44. Alyahri A, Goodman R. Validation of the Arabic strengths and difficulties questionnaire and the development and well-being assessment. East Mediterr Health J. 2006;12(Suppl 2):S138-46.

45. Sawaya H, Atoui M, Hamadeh A, Zeinoun P, Nahas Z. Adaptation and initial validation of the patient health questionnaire - 9 (PHQ-9) and the generalized anxiety disorder - 7 questionnaire (GAD-7) in an Arabic speaking Lebanese psychiatric outpatient sample. Psychiatry Res. 2016;239: 245-52. https://doi.org/10.1016/j.psychres.2016.03.030.

46. SAS Institute Inc. Base SAS 9.3 Procedures Guide. Cary NSII. 2011.

47. Lim GY, Tam WW, Lu Y, Ho CS, Zhang MW, Ho RC. Prevalence of depression in the community from 30 countries between 1994 and 2014. Sci Rep. 2018, 8(1):2861. https://doi.org/10.1038/s41598-018-21243-x.

48. Löwe B, Decker O, Müller S, Brähler E, Schellberg D, Herzog W, et al. Validation and standardization of the generalized anxiety disorder screener (GAD-7) in the general population. Med Care. 2008;46(3):266-74. https://doi. org/10.1097/MLR.0b013e318160d093.

49. McLean CP, Asnaani A, Litz BT, Hofmann SG. Gender differences in anxiety disorders: prevalence, course of illness, comorbidity and burden of illness. J Psychiatr Res. 2011;45(8):1027-35. https://doi.org/10.1016/j.jpsychires.2011. 03.006 . 
50. Borkovec TD, Ray WJ, Stöber J. Worry: a cognitive phenomenon intimately linked to affective, physiological and interpersonal behavioral processes. Cogn Ther Res. 1998;22(6):561-76. https://doi.org/10.1023/A:1018790003416.

51. Paulesu E, Sambugaro E, Torti T, Danelli L, Ferri F, Scialfa G, et al. Neural correlates of worry in generalized anxiety disorder and in normal controls: a functional MRI study. Psychol Med. 2010;40(1):117-24. https://doi.org/10.101 7/S0033291709005649.

52. Sun X, So SH, Chan RCK, Chiu CD, Leung PWL. Worry and metacognitions as predictors of the development of anxiety and paranoia. Sci Rep. 2019;9(1): 14723. https://doi.org/10.1038/s41598-019-51280-z.

53. Harper CA, Satchell LP, Fido D, Latzman RD. Functional fear predicts public health compliance in the COVID-19 pandemic. Int I Ment Heal Addict. 2020; 27:1-14.

54. Motta Zanin G, Gentile E, Parisi A, Spasiano D. A Preliminary Evaluation of the Public Risk Perception Related to the COVID-19 Health Emergency in Italy. Int J Environ Res Public Health. 2020;17(9):3024

55. Liao Q, Cowling BJ, Lam WW, Ng DM, Fielding R. Anxiety, worry and cognitive risk estimate in relation to protective behaviors during the 2009 influenza a/H1N1 pandemic in Hong Kong: ten cross-sectional surveys. BMC Infect Dis. 2014;14(1):169. https://doi.org/10.1186/1471-2334-14-169.

56. Eisenberg SL, Eisenberg MJ. Smoking cessation during the COVID-19 epidemic. Nicotine Tobacco Res. 2020;22(9):1664-5. https://doi.org/10.1093/ ntr/ntaa075.

57. Heerfordt C, Heerfordt IM. Has there been an increased interest in smoking cessation during the first months of the COVID-19 pandemic? A Google Trends study. Public Health. 2020;183:6-7. https://doi.org/10.1016/.jpuhe.202 0.04.012.

58. Vardavas Cl, Nikitara K. COVID-19 and smoking: a systematic review of the evidence. Tob Induc Dis. 2020;18:20.

59. Peretti-Watel P, Seror V, Cortaredona S, Launay O, Raude J, Verger P, et al. The COCONAL group. A future vaccination campaign against COVID-19 at risk of vaccine hesitancy and politicisation. Lancet Infect Dis. 2020;20(7):76970.

60. Alsuwaidi AR, Elbarazi I, Al-Hamad S, Aldhaheri R, Sheek-Hussein M, Narchi H. Vaccine hesitancy and its determinants among Arab parents: a crosssectional survey in the United Arab Emirates. Hum Vaccin Immunother. 2020;16(12):3163-9.

61. Tang $S$, Xiang M, Cheung T, Xiang YT. Mental health and its correlates among children and adolescents during COVID-19 school closure: the importance of parent-child discussion. J Affect Disord. 2021;279:353-60. https://doi.org/10.1016/j.jad.2020.10.016.

62. Ravens-Sieberer U, Kaman A, Erhart M, Devine J, Schlack R, Otto C. Impact of the COVID-19 pandemic on quality of life and mental health in children and adolescents in Germany. Eur Child Adolesc Psychiatry. 2021. https://doi. org/10.1007/s00787-021-01726-5.

63. O'Sullivan K, Clark S, McGrane A, Rock N, Burke L, Boyle N, et al. A qualitative study of child and adolescent mental health during the COVID-19 pandemic in Ireland. Int J Environ Res Public Health. 2021;18(3):1-15.

64. Orgilés M, Morales A, Delvecchio E, Mazzeschi C, Espada JP. Immediate Psychological Effects of the COVID-19 Quarantine in Youth From Italy and Spain. Front Psychol. 2020;11:579038.

65. Beesdo K, Knappe S, Pine DS. Anxiety and anxiety disorders in children and adolescents: developmental issues and implications for DSM-V. Psychiatr Clin North Am. 2009;32(3):483-524. https://doi.org/10.1016/.jpsc.2009.06.002.

66. Geldsetzer P. Use of rapid online surveys to assess People's perceptions during infectious disease outbreaks: a cross-sectional survey on COVID-19. J Med Internet Res. 2020;22(4):e18790. https://doi.org/10.2196/18790.

\section{Publisher's Note}

Springer Nature remains neutral with regard to jurisdictional claims in published maps and institutional affiliations.

Ready to submit your research? Choose BMC and benefit from:

- fast, convenient online submission

- thorough peer review by experienced researchers in your field

- rapid publication on acceptance

- support for research data, including large and complex data types

- gold Open Access which fosters wider collaboration and increased citations

- maximum visibility for your research: over $100 \mathrm{M}$ website views per year

At BMC, research is always in progress.

Learn more biomedcentral.com/submissions 